\title{
The Welfare State and Equality? Stratification Realities and Aspirations in Three Welfare Regimes
}

\author{
Patrick Sachweh and Sigrun Olafsdottir
}

Welfare regimes differ in their impact on social inequality in important ways. While previous research has explored the shape of stratification across nations and citizens' normative attitudes towards inequality, scant attention has been given to citizens' perceptions of actual stratification across welfare regimes. Using the 1999 International Social Survey Programme, we compare perceptions of inequality in Germany, Sweden, and the United States. More specifically, we ask how the stratification reality in each country is assessed by its citizens, whether it meets their stratification aspirations, and whether these perceptions differ systematically both across and within welfare regimes. Our results show that perceptions vary in a clear and meaningful way across countries as well as between different social groups within a given welfare regime. For instance, Americans are more likely to view society as unequal, but only slightly more likely to prefer that extent of inequality. Conversely, the Swedish clearly view their society as more equal than citizens in the United States and Germany, yet not nearly as equal as they would like it to be. Our multivariate results reveal important similarities and differences as well, such as socio-economic cleavages in the United States, and cleavages between labour market insiders and outsiders in Germany.

\section{Introduction}

Welfare states influence the structure of social inequality within and across countries (Esping-Andersen, 1990; Korpi and Palme, 1998; Kenworthy, 1999; DiPrete, 2002; Palme, 2006; Scruggs and Allan, 2008). Consequently, research has pointed out how the welfare state impacts stratification in terms of opportunities and outcomes (e.g. Esping-Andersen, 1990, 2004, 2005; Korpi and Palme, 1998; Goodin et al., 1999; Beller and Hout, 2006; Olafsdottir, 2007). Furthermore, research on attitudes towards inequality and the welfare state has been intensively occupied with opinions toward specific policies or broad normative ideals, such as equity or redistribution (e.g. Kluegel and Smith, 1986; Kelley and Evans, 1993; Svallfors, 1993, 1997, 2003; Roller, 1995; Gijsberts, 2002; Linos and West, 2003; Noll and Roberts, 2003; Kikuzawa, Olafsdottir and Pescosolido, 2008). Yet, less is known about how the public perceives inequality and what kind of inequality they are willing to tolerate. In this article, we evaluate how citizens assess the structure of social inequality and what shape of stratification they would prefer. Given the systematic differences in how welfare states impact stratification (Esping-Andersen, 1990; Scruggs and Allan, 2008), we 
look at aggregate differences as well as social cleavages within countries.

Public attitudes not only provide a window into citizens' expectations about inequality but have also been singled out as an important driving force shaping social policy (Pierson, 1994; Stimson, MacKuen and Erikson, 1995; Brooks and Manza, 2006; Steensland, 2006). Consequently, an examination of citizens' assessments and aspirations about social stratification sheds light on an important aspect of the cultural foundations of the welfare state (Steensland, 2006; van Oorschot, 2007).

Using data from the 1999 International Social Survey Programme (ISSP), we look at citizens' perceptions and aspirations of social inequality in the United States, Germany, and Sweden. Stratification differs sharply across these nations, largely due to the different role of the state, the market, and the family within the policy sphere (Esping-Andersen, 1990). The specific configurations of how these institutions interact with one another are typically called 'welfare regimes'. To better understand why perceptions of stratification realities and preferences for ideal stratification may vary across nations, we draw upon the welfare regime literature to frame the context of respondents' perceptions in each nation. As we will discuss further, each of our nations represents the 'ideal type' of three different welfare regimes: the United States, Germany, and Sweden are crucial cases of liberal, conservative, and social-democratic welfare regimes, respectively (Esping-Andersen, 1990).

We focus on a small sample of nations rather than a large- $\mathrm{N}$ sample to provide a more nuanced description of the institutional arrangements in each country (Ebbinghaus, 2005; Kittel, 2006). This approach allows for more detailed comparisons of the links between individual characteristics and perceptions of stratification in each country. We refer to perceptions of the stratification order as 'perceived stratification realities', and to people's respective preferences as 'stratification aspirations'.

Our article proceeds in four steps. First, we develop contrasting hypotheses about how and why these perceptions may differ between individuals. Second, we describe the institutional contexts of the three regimes and appropriate our general hypotheses to the specific countries. Third, we present the results of our empirical analysis, showing both aggregate differences in perceptions and preferences across countries as well as social cleavages within each country. We conclude by discussing how our results relate to prior research and recent theoretical developments in the welfare state literature.

\section{Stratification Realities and Stratification Aspirations}

Achieving greater socio-economic equality has long been an important goal of modern welfare states (Marshall, 1950; Wilensky, 1975; Flora, Alber and Kohl, 1977), and the redistribution of income from rich to poor has been one of the most important strategies in realizing this goal (Korpi and Palme, 1998; Bradley et al., 2003; Alesina and Glaeser, 2004). Although current pressures for reform may result in less emphasis on policies aimed towards greater equality, Kenworthy and Pontusson (2005) have shown that many welfare states have recently intensified redistribution in response to increased market inequality. Hence, reducing inequality still appears to be important in contemporary welfare states.

Therefore, and because relatively scant research has focused on attitudes toward inequality per se, we build on micro-theoretical assumptions originally introduced in studies of preferences for redistribution in order to investigate citizens' perceived stratification realities and stratification aspirations. Within this framework, attitudes towards inequality and governmental redistribution are primarily viewed as being based on people's material self-interest. ${ }^{1}$ The basic argument is that people will be in favour of greater equality and welfare state intervention if they can hope to gain from it (Meltzer and Richard, 1981; Pescosolido, Boyer and Tsui, 1985). Since there tends to be inequality in all Western democracies, albeit at different levels, a large proportion of the population can-at least in theoryhope to gain from redistributive policies aiming to increase equality. Consequently, in societies with higher levels of inequality, a higher proportion of people would potentially stand to profit from demanding greater equality and redistribution (cf. also Romer, 1975; Rehm, 2007).

Although this argument seems intuitively compelling, empirical investigations have found relatively weak support (Kenworthy and McCall, 2008). One reason may be that people base their perceptions of inequality not on the level of market inequality, as suggested by Meltzer and Richard (1981), but on the shape of stratification after welfare state intervention (Kenworthy and McCall, 2008: 60f.). According to Pierson's (1994) argument about 'policy feedback', existing institutions and social policies influence actors' endowments with material resources-and hence their self-interest. ${ }^{2}$ Therefore, if the welfare state effectively counteracts market-generated inequalities, people profiting from these strategies might be satisfied with their 
position in society and therefore not demand greater equality. Self-interest is thus not inherent to individuals but shaped by institutional contexts.

In line with this argumentation, we assume that individuals' self-interest is based on whether they are positively affected by welfare state-induced changes in the social structure of their societies or not. We do not, however, confine this to the receipt of material cash benefits. For example, studies on government involvement in health care point to the importance of social services by showing that those in more vulnerable positions (e.g. the elderly, women, those with low levels of education and/or income) are more supportive of the role of the government in providing health care as well as increased spending on health (Pescosolido, Boyer and Tsui, 1985; Hayes and VandenHeuvel, 1996; Kikuzawa, Olafsdottir and Pescosolido, 2008). Furthermore, welfare regimes also influence labour market structures, employment patterns, and gender roles (Geist, 2003; Fuwa, 2004). People may thus also consider the wider implications of the welfare state in determining whether they are positively or negatively affected by it. Recent research shows that groups typically found to be less dependent on the welfare state-e.g. men, people with higher incomes, or the self-employed-are positive about the social consequences of the welfare state (such as increased overall happiness, just distribution of wealth, more equal opportunities) (van Oorschot, 2010 , p. 27). By contrast, having experienced means-testing tends to be associated with lower levels of political trust and less support for redistribution (Kumlin, 2004, p. 215). In our view, it is therefore important to consider the institutional configuration of a given welfare regime and how citizens experience its personal and societal impact at large in trying to determine which groups are positively affected by a specific welfare regime and how this affects their perceptions of and preferences for stratification. Specifically, we propose a set of contrasting hypotheses for each aspect:

1a) Those favoured by a specific welfare regime will be more likely to assess the stratification order of their society as egalitarian (satisfaction hypothesis: perception).

1b) Those not benefiting from a specific welfare regime should be less likely to assess the stratification order in their societies as egalitarian (disappointment hypothesis: perception).

2a) Those favoured by a specific welfare regime will be less likely to prefer a more equal society (satisfaction hypothesis: aspiration). 2b) Those not benefiting from a specific welfare regime should be more likely aspire to a more equal society (disappointment hypothesis: aspiration).

These general hypotheses will guide the empirical investigation of group differences in perceived stratification realities and stratification aspirations. Which specific groups do and do not benefit from welfare state intervention varies across regimes. As we extend previous research by focusing on perceptions of and preferences for equality, group cleavages in our case may also differ from those in prior studies that focus on attitudes towards redistribution and/or specific policies. As argued above, people's understanding of their self-interest and their preferences for inequality are likely to be embedded within existing institutional arrangements and their perceptions thereof. In the following section we describe the respective stratification realities in the United States, Germany, and Sweden and appropriate our hypotheses to each context.

\section{The Welfare State as a Creator of Stratification}

Esping-Andersen's (1990) three worlds of welfare capitalism is the most widely used categorization of welfare states. He distinguishes between liberal, conservative and social-democratic welfare states. ${ }^{3}$ Importantly, in this work, the welfare state is characterized not only as 'a mechanism that intervenes in, and possibly corrects, the structure of inequality; it is, in its own right, a system of stratification' (Esping-Andersen, 1990, p. 23). Yet, welfare regimes influence the shape of stratification differently across nations. For example, one type may cultivate status differences while another one may create dualisms between various groups and yet another one promotes universal social rights. These distinctions parallel the differentiation between liberal, conservative, and social-democratic welfare regimes.

It has been rightly pointed out that regimes represent ideal-types whose real-life incorporations might deviate from the ideal-typical world they describe (Jaeger, 2006). Yet, it is possible to identify genuine stratification effects for each regime (Esping-Andersen, 1990; Scruggs and Allan, 2008). We now describe the different institutional contexts as well as the empirical realities that characterize the shape of stratification in the United States, Germany, and Sweden in order to derive more specific hypothesis about group differences in assessments of the stratification order. 


\section{Stratification in the Liberal Welfare State}

In general, liberal welfare states like the United States make little efforts to mitigate market-generated inequalities (Korpi and Palme, 1998; Goodin et al., 1999). While (pre-government) market-based income inequality tends to be similar across different welfare regimes, post-government inequality is significantly lower in social-democratic and conservative regimes than in liberal ones (Goodin et al., 1999, p. 176). Poverty rates are also higher, poverty is more severe, and poverty spells last longer in liberal as compared to other welfare regimes (Goodin et al., 1999, p. 154ff.; Kenworthy, 1999; Brady, 2003; Fouarge and Layte, 2005).

Yet, liberal welfare states do not leave their citizens completely unprotected from market forces. Among the most important measures of social protection are means-tested poor relief or income maintenance programmes. These policies are largely aimed at the genuinely poor, often emphasizing self-help and individual responsibility, and service use is associated with stigma (Titmuss, 1968; Sachweh, Ullrich and Christoph, 2007). For most citizens, however, services are provided through the market, either directly or through private or social insurance. Thus, the liberal welfare regime divides citizens into three groups, with one group at the bottom relying on stigmatizing poor relief, another in the middle as clients of social insurance, and a final group at the top sufficiently privileged to derive its welfare from the market (Esping-Andersen, 1990, p. 65). The United States is frequently viewed as the ideal type of the liberal welfare regime and likely the country where the mechanisms play out most clearly. This can be seen in the highest amount of private health care spending on the one hand side and high levels of means-tested poor-relief on the other hand side (Scruggs and Allan, 2008).

However, while inequality of outcomes tends to be high in liberal welfare states, they harbour a myth of equal opportunities. This seems to be particularly the case in the United States, where a majority of the population overestimates its prospects for social and economic mobility (DiPrete, 2007). Although it is certainly true that the proportion of the population participating in post-secondary education is higher in the United States than in many European countries, access to tertiary education is also more unequal (Goodin et al., 1999, p. 179). Since access to higher education is of crucial importance for weakening the link between social origin and occupational destination in liberal welfare states (Beller and Hout, 2006, p. 362), inequality of outcomes does not seem to be off-set by greater mobility.
In this context, socio-economic cleavages are assumed to be at the core of how citizens view society (Esping-Andersen, 1990, p. 228; Svallfors, 1997, p. 285). Thus, we would expect that those favoured by the institutional set-up of the liberal welfare state in the United States will be those in higher socioeconomic positions who are more likely to have their welfare needs met via market provision. Consequently, they should be more likely to assess the United States as egalitarian (satisfaction hypothesis: perception), while those not benefiting as much from the liberal welfare state, i.e. people in lower socio-economic positions, should be less likely to do so (disappointment hypothesis: perception). Conversely, those benefiting from the liberal welfare arrangement should be less likely to prefer a more egalitarian society (satisfaction hypothesis: aspiration) while those not benefiting from it should be more likely aspire to a more equal society (disappointment hypothesis: aspiration).

\section{Stratification in the Conservative Welfare State}

Stratification in conservative welfare states is usually less pronounced than in liberal ones, yet they also maintain (and often reinforce) market-generated inequalities and occupational status distinctions (Esping-Andersen, 1990). Conservative welfare states are more encompassing than liberal welfare states in terms of the risks they cover and often operate on the basis of social insurance systems whose benefits are closely tied to the labour-market earnings of individuals (Esping-Andersen, 1990, p. 27). The emphasis is on the preservation of status and the provision of security and stability over the life-course; redistribution across classes is fairly low. Policies are paternalistic, as reflected for instance in the privileges enjoyed by civil servants in countries like France or Germany (Esping-Andersen, 1990, p. 59).

The German welfare state is often cited as the archetype of a conservative welfare regime (Offe, 1998; Leitner and Lessenich, 2003). Albeit Germany faced a decline in the occupational fragmentation of the welfare system in recent years-e.g. in terms of pension expenditures devoted to public employees (as a percentage of GDP) and in the number of occupationally distinct pension schemes (Scruggs and Allan, 2008) - the conservative elements of the German welfare state are still more pronounced than in the United States or Sweden. For instance, status preservation among the elderly is greater in corporatist than in liberal welfare regimes (Palme, 2006, p. 399). 
Furthermore, adding to the conservative nature of the German welfare state, comparative stratification research has repeatedly shown that social mobility is particularly low compared to other European nations (e.g. Erikson and Goldthorpe, 1992; Müller and Pollak, 2004). The conservative welfare regime can be thought to influence this situation since equality of opportunity seems to be related to the way family policies are set up. As German family policy continues to be centred around the 'male-breadwinner' model, it may contribute to unequal opportunities (Sørensen, 2006). Especially the limited number of public child care facilities seems to discourage greater female labour force participation in Germany, which could reduce income disparities among households and thus foster more equal opportunities for children. Given that income redistribution in conservative regimes is mostly of a horizontal nature (i.e. redistribution across the life-cycle), the German welfare state can be characterized by moderate equality of outcome and low equality of opportunity.

Within the German conservative welfare regime, benefits are closely linked to labour market position and cleavages are likely between 'insiders' with a good position and adequate social insurance, and 'outsiders' (e.g. those in part-time or precarious employment and the unemployed) (Esping-Andersen, 1990, p. 227; Svallfors, 1997, p. 285). Therefore, we expect that the insiders of the labour market will be more likely to view society as equal (satisfaction hypothesis: perception), while the outsiders will be more likely to view Germany as unequal (disappointment hypothesis: perception). In contrast, labour market insiders should be less likely to aspire to a more equal society (satisfaction hypothesis: aspiration), while labour market outsiders should be more likely to do so (disappointment hypothesis: aspiration).

\section{Stratification in the Social-democratic Welfare State}

The social-democratic welfare regime represents the model with the strongest equalizing effects of the three regime types distinguished by Esping-Andersen (1990). Through its focus on universal programmes and the provision of individual autonomy (not only from the market but also from the family), the social democratic welfare regime achieves a considerable redistributive and decommodifying effect. Universal social programmes encompass large parts of the population and grant equal benefits to all, regardless of income or status.
It is not surprising that the social-democratic welfare regime usually performs best in comparative assessments of social policy outcomes (Korpi and Palme, 1998; Goodin et al., 1999). Scruggs and Allan (2008) for instance find the greatest coverage rates and lowest benefit inequality regarding social programmes in social democratic countries such as Sweden, Norway, Finland, and Denmark-especially when compared to the United States and Germany. Moreover, Goodin et al. (1999, p. 186) concluded that social-democratic welfare regimes achieve greater success in reducing income inequality in the short and especially in the long run. Furthermore, comparative analyses of poverty dynamics reveal that poverty rates are lower, poverty is less severe, and poverty spells are of shorter duration in social democratic welfare states (Goodin et al., 1999; DiPrete, 2002; Brady, 2003; Fouarge and Layte, 2005).

The Scandinavian countries also achieve a remarkable degree of equality of opportunity (Erikson and Jonsson, 1996) and exhibit low levels of child poverty (Esping-Andersen, 2005; Palme, 2006), which some observers attribute to the 'dual-earner' family policies pursued in these welfare regimes (e.g. EspingAndersen, 2005; Sørensen, 2006). These policies are characterized by parental leaves, a strong encouragement of female labour force participation, and the availability of public child care from early childhood on. Thus, the social-democratic welfare regime combines relatively high equality of outcomes with high levels of equality of opportunity.

The Swedish welfare state is often characterized as the prototype of the social-democratic welfare regime. It is universalistic in nature and generous in terms of benefit levels. This is possible because the majority of the working age population is active in the labour force. Sweden has a large public sector with a predominantly female employee body, likely resulting in cleavages based on gender and sector (EspingAndersen, 1990, p. 227; Svallfors, 1997, p. 285). Therefore, we expect that those favoured by the welfare state will be women and/or employees of the public sector who should be more likely to view Sweden as equal (satisfaction hypothesis: perception). Those not benefiting as much from welfare state intervention-i.e. men and/or employees in the private sector-should be less likely to assess their society as egalitarian (disappointment hypothesis: perception). Conversely, women and/or employees in the public sector should be less likely to prefer a more egalitarian society (satisfaction hypothesis: aspiration), while men and/or private sector workers should be more likely to do so (disappointment hypothesis: aspiration). 
Table 1 Summary of hypothesized effects by country

\section{Perceived stratification reality}

More likely to perceive stratification reality as egalitarian

\section{Stratification aspirations}

Less likely to prefer more egalitarian stratification order

(satisfaction hypothesis)

United States

Germany

Sweden

Disadvantaged by welfare regime (disappointment hypothesis)

United States

Germany

Sweden
Higher socio-economic positions

Labour market insiders (full-time)

Women, public sector employees
Less likely to perceive stratification reality as egalitarian
More likely to prefer more egalitarian stratification order
Hypotheses for all three countries are summarized in Table 1.

\section{Data and Methods}

In order to test these hypotheses, we use data from the 1999 ISSP module on 'social inequality' for the United States, Germany, and Sweden. Our dependent variables are (i) perceptions of a country's stratification order'perceived stratification reality', and (ii) preferences for a stratification order-'stratification aspirations'. Respondents were shown a card with five different shapes of society, depicting (i) a society with a small elite at the top, very few people in the middle and the great mass of people at the bottom (small elite), (ii) a pyramid with a small elite at the top, more people in the middle, and most at the bottom (pyramid), (iii) a pyramid except that just a few people are at the very bottom (christmas tree), (iv) most people located in the middle (middle), and (v) many people near the top, and only a few near the bottom (rich). Respondents were asked to indicate (i) what they thought their society actually looked like and (ii) what it should look like (see Figure A1). Although the formulation of the question itself does not indicate an ordering of the categories along an inequality/ equality'-dimension, there is a clear underlying ordering to at least some of the inequality shapes. All five pictograms represent different shapes of unequal societies, but the proportions of the population holding lower, middle, or upper social positions vary. We assume that the diagrams with few people in lower social positions are perceived to be more equal than the ones with many people in low social positions. For instance, it is clear that the small elite diagram (Type 1) represents higher levels of inequality (with
Low socio-economic positions Men, private-sector employees most people at the bottom of society) than the middle diagram (Type 4, with most people in the middle). However, as the ordering of some adjacent categories is not entirely unambiguous (for instance, is Type 4, with most in the middle, more unequal than Type 5 , with most near the top and very few at the bottom?), it is inappropriate to use statistical models that require an ordered dependent variable, but in our discussion we view some types as more unequal than others.

Our main independent variables are two indicators for respondents' socio-economic position (education and income) ${ }^{4}$ employment status, gender, and the employment sector. Furthermore, we control for age, region (East Germany), and people's support for redistribution, but do not formulate specific hypotheses for these variables. Following other comparative work, income is recoded into a set of binary variables, with relative affluence representing the upper 20 per cent, relative poverty representing the lower 20 per cent, and the remaining 60 per cent of the income distribution representing the income middle and serving as the reference group in the multivariate analyses (Olafsdottir, 2007; Bolzendahl and Olafsdottir, 2008). Education is a binary variable indicating whether a respondent has tertiary education or not. Employment status differentiates between five categories: full-time employment, part-time employment, unemployed, retired, and not in labour force (e.g. students, housewives, etc.). Respondents' sex is a dichotomous variable $(1=$ female; $0=$ male $)$ as is the variable for employment sector indicating whether a respondent is employed in the public (1) or private sector (0). For Sweden, we include an interaction term for women working in the public sector. We control for age (in years), individuals' support for redistribution ${ }^{5}$ (on a 5-point scale, with higher 
numbers indicating stronger support), and in Germany for region $(1=$ East Germany). As prior research has shown, younger people tend to be less accepting of inequality due to their (alleged) post-materialist value orientations (e.g. Kelley and Evans, 1993; Svallfors, 1993, p. 276f.), as are people holding egalitarian justice beliefs (Lewin-Epstein, Kaplan and Levanon, 2003; Sachweh, Ullrich and Christoph, 2007) and East Germans given their socialization in a former socialist country (Roller, 1997). A full table including descriptive statistics is included in the appendix (Table A1). Given the observed differences between East and West Germany, we provide the descriptive statistics separately for Germany. However, the small sample size of each sample, if separated, does not allow us to distinguish between West and East Germany in our regression models.

Although it can be argued that our dependent variables have some underlying ordering, both represent nominal categorical outcomes. Therefore, multinomial logit regression models are most appropriate (Long, 1997; Long and Freese, 2001). For testing the hypotheses derived in the previous section, we estimate two multinomial logit models for each country (one per dependent variable). ${ }^{6}$ In order to ease interpretation of our results, we only present results for those independent variables for which we hypothesize significant effects. Full tables can be found in the appendix (Tables A2-A4).



\section{Stratification Realities and Aspirations across Countries}

Before investigating the hypothesized regime-specific cleavages, we illustrate the aggregate differences in perceived stratification realities and stratification aspirations in the three countries. Figures 1 and 2 display which percentage of the population in each country perceives a particular stratification reality and, respectively, which percentage of the population aspires to a particular stratification order.

Figure 1 shows that US citizens perceive their country to be highly unequal. A sizeable portion (17.5 per cent) characterizes their society as having few people on top and the majority at the bottom, and over half of the US respondents (52 per cent) view the US stratification order as having a pyramid-like shape (pyramid, christmas tree), with the higher proportion of those respondents (32.7 per cent) perceiving the more unequal shape. Roughly a third of the US citizens (30.6 per cent) view their society as being dominated by the middle class.

The perception of the German stratification reality differs between the Eastern and Western part of the country. As expected, West Germans perceive the stratification order to be somewhat less unequal than East Germans. While about 12 per cent of West Germans believe that their society is characterized by a small elite and most people in the bottom, almost

Figure 1 Perceived stratification realities in the United States, Germany, and Sweden. Source: ISSP 1999; $N=1.075$ (United States), 766 (West Germany), 441 (East Germany), 1.031 (Sweden) 


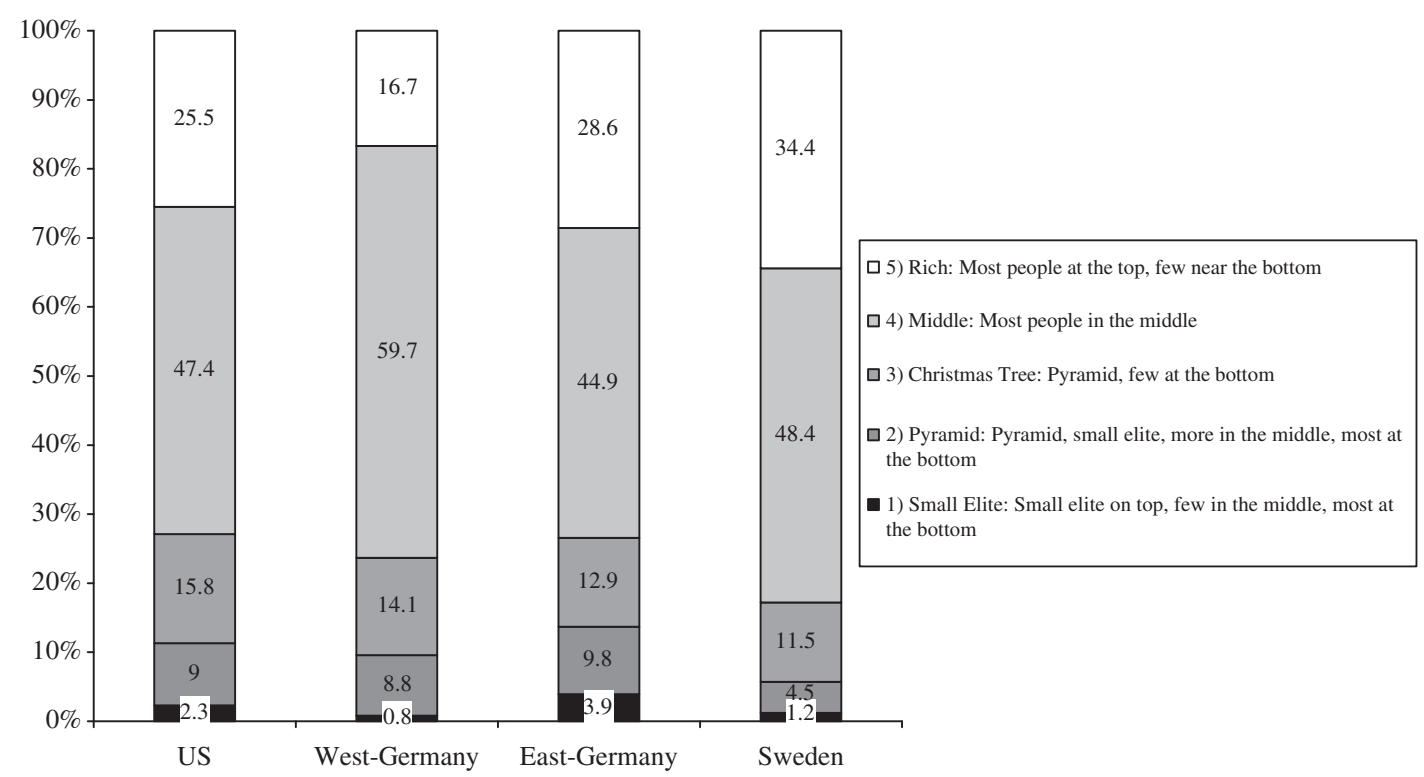

Figure 2 Stratification aspirations in the United States, Germany, and Sweden. Source: ISSP 1999; $N=1.075$ (United States), 766 (West Germany), 441 (East Germany), 1.031 (Sweden)

20 per cent of the East Germans hold this view. Almost 59 per cent of the West Germans believe that the German society has a pyramid-like shape (pyramid, christmas tree), while 56 per cent of the East Germans believe the same. A third of the respondents in West Germany views society dominated by the middle class, while 24.3 per cent in East Germany hold this view. Germans' perception of their stratification reality thus is split: East Germans are similar to Americans in how they evaluate the stratification order of Germany, while West Germans seem to resemble Swedes to some extent.

In Sweden, the proportion viewing Swedish society as highly unequal is smaller, though by no means negligible (11.2 per cent). As in the United States, over half of the Swedish respondents view their society as being shaped like a pyramid (54.7 per cent), with the more egalitarian view (christmas tree) being endorsed to a greater extent (29.1 per cent), and a minority of roughly 26 per cent believes that most people are at the bottom. Over a third of the Swedish respondents regard Sweden as a country dominated by a large middle class (34.2 per cent).

Figure 2 shows how these assessments correspond with the stratification order citizens prefer. There is a clear discrepancy between the shape of society citizens think to be true and the one they would want to be true in all three countries. More than two-thirds of the citizens in the United States (72.9 per cent) would prefer their society to be dominated by a sizeable middle class, and only a minority (27.1 per cent) opts for a pyramid-like shape of the United States. In Germany, egalitarian preferences are slightly greater among respondents from the Western part, of which 76.4 per cent would like Germany to consist mostly of the middle class (compared to 73.5 per cent in East Germany). Only about a fifth of the respondents in East and West would prefer one of the other shapes of the German stratification order. Finally, the Swedish respondents stand out as remarkably egalitarian. Over 80 per cent of the Swedes would prefer to live in a society that has most people in the middle class, and again only a minority (17.2 per cent) of the respondents would want their society to be shaped like a pyramid.

These aggregate differences can be meaningfully interpreted across welfare regimes: Americans view their society as highly unequal, followed by East Germans, while Swedes view their country as most equal. However, Sweden is not as equal as they would prefer. West Germans are in between: while they resemble Swedes in their assessment of the German stratification reality, they do display smaller egalitarian aspirations. East Germans again resemble Americans and appear to be somewhat more comfortable with inequality. ${ }^{7}$ These findings correspond to previous 
findings showing clear-cut regime differences in attitudes towards inequality on the aggregate level (Svallfors, 1997, 2003; Linos and West, 2003; Jaeger, 2006). However, prior evidence on regime-specific attitudinal cleavages is more ambiguous. While some researchers report evidence supporting the idea that welfare regimes create systematic attitudinal differences between social groups (Andreß and Heien, 2001; Linos and West, 2003; Jaeger, 2006) others have not been able to do so (Svallfors, 1997, 2003). Therefore, we now investigate whether there are distinct cleavages in perceived stratification realities and aspirations that align with our hypotheses. In discussing the results, we focus only on those variables for which we expect significant effects in the respective countries.

\section{Cleavages in Stratification Realities and Aspirations within Countries}

Table 2 presents results from a likelihood-ratio test of the independent variables for each model. A significant $\chi^{2}$ indicates that a particular variable affects perceptions across the five categories. This test provides an estimate of whether the variable has significant effects across the contrasts, but does not capture whether the effect is positive or negative. Therefore, these results only reflect what matters; how factors affect perceptions follows in Tables 3-5. The findings in Table 2 reveal that, as expected, attitudinal cleavages differ across countries. The general pattern of effects supports our hypotheses. We find that education (as an indicator of respondents' socio-economic position) significantly affects stratification realities and aspirations in the United States, labour market status significantly influences stratification realities and aspirations in Germany, and gender and public sector employment of women significantly affect stratification aspirations in Sweden.

We also obtain several significant effects for variables for which we do not hypothesize effects, such as part-time employment and support for redistribution in the United States, relative affluence, age, sex, region, and support for redistribution in Germany, and age, education, unemployment, and support for redistribution in Sweden. As the direction of these effects does not run counter to our hypotheses, we focus on the

Table 2 Chi-square tests for overall effects from multinominal logit analysis of the independent variables on perceived stratification realities and aspirations in the United States, Germany, and Sweden

\begin{tabular}{|c|c|c|c|c|c|c|}
\hline & \multicolumn{2}{|c|}{ United States } & \multicolumn{2}{|c|}{ Germany } & \multicolumn{2}{|c|}{ Sweden } \\
\hline & $\begin{array}{c}\text { Reality } \\
\chi^{2}\end{array}$ & $\begin{array}{c}\text { Aspiration } \\
\chi^{2}\end{array}$ & $\begin{array}{c}\text { Reality } \\
\chi^{2}\end{array}$ & $\begin{array}{c}\text { Aspiration } \\
\chi^{2}\end{array}$ & $\begin{array}{c}\text { Reality } \\
\chi^{2}\end{array}$ & $\begin{array}{c}\text { Aspiration } \\
\chi^{2}\end{array}$ \\
\hline Age & 3.28 & 4.44 & 4.71 & $15.52^{* *}$ & $32.87^{\star * *}$ & $30.90^{* * *}$ \\
\hline Female & 4.70 & 4.57 & 4.78 & $9.35^{\star}$ & 2.89 & $21.51^{* * *}$ \\
\hline College & $21.37^{\star * *}$ & $16.61^{\star * *}$ & 3.87 & 0.21 & $15.97^{\star * *}$ & 4.50 \\
\hline \multicolumn{7}{|l|}{ Income (Ref.: income middle) } \\
\hline Relative affluence & 1.43 & 3.06 & 6.25 & $10.71^{*}$ & 9.92 & 3.46 \\
\hline Relative poverty & 0.68 & 5.67 & 5.93 & 0.36 & 0.58 & 1.81 \\
\hline \multicolumn{7}{|c|}{ Employment status (Ref.: not in labour force) } \\
\hline Employed fulltime & 6.47 & 2.43 & $10.18^{*}$ & $16.27^{* *}$ & 1.38 & 3.93 \\
\hline Employed part-time & $14.74^{\star \star}$ & 4.97 & 6.94 & $10.41^{\star}$ & 3.88 & 2.18 \\
\hline Unemployed & 3.47 & 2.22 & $9.36^{*}$ & 6.70 & 3.20 & $11.68^{*}$ \\
\hline Retired & 3.14 & 4.84 & 2.13 & 4.44 & 5.83 & 6.40 \\
\hline Public sector & 3.53 & 6.99 & 5.36 & 2.95 & 3.41 & 2.11 \\
\hline East Germany & - & - & 3.22 & $26.57^{* * *}$ & - & - \\
\hline Female $\times$ public sector & - & - & - & - & 0.86 & $8.03^{*}$ \\
\hline Support for redistribution & $40.56^{\star * *}$ & $16.805^{\star \star}$ & $13.40^{*}$ & 4.95 & $49.61^{\star * *}$ & 4.20 \\
\hline LR-test & 116.27 & 86.73 & 93.64 & 97.66 & 169.69 & 108.39 \\
\hline Probability >LR & 0.00 & 0.00 & 0.00 & 0.00 & 0.00 & 0.00 \\
\hline Pseudo $R^{2}$ & 0.13 & 0.10 & 0.10 & 0.11 & 0.19 & 0.14 \\
\hline$N$ & 896 & 874 & 925 & 899 & 880 & 835 \\
\hline
\end{tabular}

Source: ISSP 1999, ${ }^{*} P<0.05,{ }^{*} P<0.01,{ }^{* * *} P<0.001$, Pseudo $R^{2}$ refers to Cragg-Uhler $R^{2}$. 
Table 3 Change in predicted probabilities for perceived stratification realities and stratification aspirations, United States

Independent
variables
Change
Categories of dependent variable

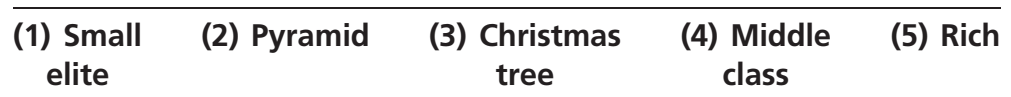

\begin{tabular}{llrrrrr}
\hline Panel 1: Realities & & & & & & \\
$\quad$ College & $0 \rightarrow 1$ & -0.09 & -0.07 & 0.08 & 0.09 & -0.01 \\
Relative affluence & $0 \rightarrow 1$ & -0.03 & -0.00 & -0.00 & 0.03 & -0.00 \\
$\quad$ Relative poverty & $0 \rightarrow 1$ & 0.00 & 0.01 & -0.00 & -0.01 & -0.00 \\
Panel 2: Aspirations & & & & & & \\
$\quad$ College & $0 \rightarrow 1$ & -0.02 & -0.04 & -0.05 & 0.06 & 0.04 \\
Relative affluence & $0 \rightarrow 1$ & 0.00 & 0.03 & 0.03 & -0.05 & -0.01 \\
Relative poverty & $0 \rightarrow 1$ & -0.00 & -0.00 & 0.06 & -0.05 & -0.02 \\
\hline
\end{tabular}

Note: $0 \rightarrow 1$ is the discrete change from 0 to 1 . Income Middle is the reference group for the income variable. Results are obtained while controlling for age, gender, employment status, employment sector, and support for redistribution. Control variables are held at their means.

Table 4 Change in predicted probabilities for perceived stratification realities and stratification aspirations, Germany

\begin{tabular}{|c|c|c|c|c|c|c|}
\hline \multirow[t]{2}{*}{ Independent variables } & \multirow[t]{2}{*}{ Change } & \multicolumn{5}{|c|}{ Categories of dependent variable } \\
\hline & & $\begin{array}{l}\text { (1) Small } \\
\text { elite }\end{array}$ & (2) Pyramid & $\begin{array}{c}\text { (3) Christmas } \\
\text { tree }\end{array}$ & $\begin{array}{l}\text { (4) Middle } \\
\text { class }\end{array}$ & (5) Rich \\
\hline \multicolumn{7}{|l|}{ Panel 1: Realities } \\
\hline Employed fulltime & $0 \rightarrow 1$ & 0.00 & 0.13 & -0.09 & -0.05 & 0.00 \\
\hline Employed part-time & $0 \rightarrow 1$ & -0.07 & 0.20 & -0.08 & -0.05 & 0.00 \\
\hline Unemployed & $0 \rightarrow 1$ & 0.05 & 0.18 & -0.11 & -0.13 & 0.00 \\
\hline Retired & $0 \rightarrow 1$ & -0.03 & 0.00 & -0.01 & 0.04 & 0.01 \\
\hline \multicolumn{7}{|l|}{ Panel 2: Aspirations } \\
\hline Employed fulltime & $0 \rightarrow 1$ & -0.00 & -0.07 & 0.11 & 0.06 & -0.10 \\
\hline Employed part-time & $0 \rightarrow 1$ & -0.01 & -0.09 & 0.03 & 0.10 & -0.03 \\
\hline Unemployed & $0 \rightarrow 1$ & -0.00 & -0.05 & 0.16 & -0.02 & -0.09 \\
\hline Retired & $0 \rightarrow 1$ & -0.00 & -0.05 & 0.08 & -0.02 & -0.00 \\
\hline
\end{tabular}

Note: $0 \rightarrow 1$ is the discrete change from 0 to 1 . Not in labour force is the reference group for employment status. Results are obtained while controlling for age, gender, income, education, employment sector, region (East Germany), and support for redistribution. Control variables are held at their means.

interpretation of the hypothesized effects. Full results are reported in Tables A1-A3.

We now turn to a more detailed discussion of our hypothesis and look at changes in predicted probabilities (Tables 3-5). The coefficients for the different categories of the dependent variable in Tables 3-5 display the magnitude of the change in the predicted probability of an outcome for a given change in the independent variable (cf. Long, 1997, p. 167). All results are obtained while controlling for the other variables we do not address explicitly in our hypotheses (i.e. age, gender, employment status, employment sector, and support for redistribution in the United States; age, gender, income, education, employment sector, region, and support for redistribution in Germany; and age, education, income, employment status, and support for redistribution in Sweden). In the respective models, control variables are being held at their means.

\section{Cleavage Structures in the United States}

For the United States, we expect socio-economic cleavages to emerge and therefore consider the effects of education and income on stratification realities and aspirations. Looking at the effects of education on perceived stratification realities (Table 3, Panel 1), we 
Table 5 Change in predicted probabilities in perceived stratification realities and stratification aspirations, Sweden

Independent variables

Change

Categories of dependent variable

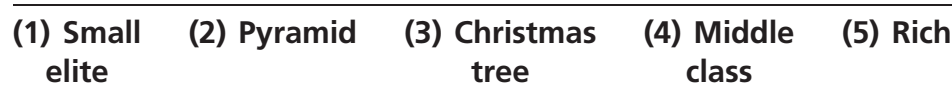

\begin{tabular}{|c|c|c|c|c|c|c|}
\hline \multicolumn{7}{|l|}{ Panel 1: Realities } \\
\hline Female & $0 \rightarrow 1$ & -0.01 & 0.02 & -0.07 & 0.06 & 0.00 \\
\hline Public sector & $0 \rightarrow 1$ & 0.03 & 0.02 & -0.04 & -0.00 & 0.00 \\
\hline Female $\times$ public sector & $0 \rightarrow 1$ & -0.02 & -0.04 & 0.01 & -0.03 & -0.00 \\
\hline \multicolumn{7}{|l|}{ Panel 2: Aspirations } \\
\hline Female & $0 \rightarrow 1$ & -0.73 & 0.02 & 0.02 & 0.33 & 0.35 \\
\hline Public sector & $0 \rightarrow 1$ & -0.00 & 0.01 & -0.01 & -0.03 & 0.03 \\
\hline Female $\times$ public sector & $0 \rightarrow 1$ & 1.00 & -0.05 & -0.07 & -0.49 & -0.38 \\
\hline
\end{tabular}

Note: $0 \rightarrow 1$ is the discrete change from 0 to 1 . Results are obtained while controlling for age, education, income, employment status, and support for redistribution. Control variables are held at their means.

find that having a college education decreases the probability of perceiving the United States as unequal (small elite or pyramid) and it increases the probability of perceiving the United States as having a more middle-class based shape of stratification (Christmas tree or middle class). Americans with a college education thus neither perceive American society to be highly unequal nor very egalitarian. This finding is in line with the satisfaction hypothesis for perceptions. However, we do not find significant effects for income (see Table 2). Neither does being relatively affluent nor being relatively poor significantly affect how one views the American stratification order. The absence of an effect for those in disadvantaged positions rejects the disappointment hypothesis for perceptions.

Regarding stratification aspirations (Table 3, Panel 2), we observe that college education decreases the probability of preferring one of the more unequal stratification orders (small elite, pyramid), while it increases the probability of preferring a more egalitarian stratification order (middle class or rich). Being relatively affluent does not significantly influence stratification aspirations. These findings do not support our satisfaction hypothesis for aspirations but instead indicate that those positively affected by the liberal welfare regime would prefer a more equal society. The absence of a significant effect for relative poverty and the positive effect for college education indicate that the disappointment hypothesis for aspirations is not supported. In sum, socio-economic cleavages with regard to perceived stratification realities and aspirations are present in the United States, but appear to be moderate.

\section{Cleavage Structures in Germany}

Due to the direct link of welfare to the labour market in the conservative German welfare state, we expect attitudinal cleavages to emerge between labour market insiders and outsiders. The assessments of the German stratification reality (Table 4, Panel 1) show that being unemployed increases the probability of an unequal perception of Germany (small elite, pyramid) and that it decreases the probability of a middle-class based assessment of the German stratification order (Christmas tree, middle class). Hence, the unemployed view Germany as more unequal. This is in line with the disappointment hypothesis for perceptions, indicating that those outside the labour market have a more inegalitarian image of the German stratification order. Yet, as we do not find a significant effect for part-time employment, the disappointment hypothesis for perceptions receives partial support. Moreover, we also find that those in full-time employment regard the German stratification order to be relatively unequal. Being employed full-time increases the probability of perceiving a rather inegalitarian stratification order (small elite or pyramid), and it decreases the probability of a more egalitarian perception of German society (Christmas tree and middle class). These findings do not support the satisfaction hypothesis for perceptions of the German stratification order.

Looking at stratification aspirations (Table 4, Panel 2), we observe significant effects for labour market insiders as compared to outsiders. Being employed full-time increases the probability of preferring a society with a large middle class (middle class) and one like a pyramid with few at the bottom (Christmas tree), while it decreases the probability of preferring a 
society with many at the bottom (small elite), one shaped like a pyramid (pyramid) and one with most people at the top (rich). This does not fully support the satisfaction hypothesis for aspirations but instead indicates that the full-time employed show egalitarian aspirations, though these are curtailed to some extent. For those in part-time employment, we observe somewhat greater egalitarian aspirations as being employed part-time increases the probability of preferring a society with a large middle class and one shaped like a pyramid with few at the bottom, while it decreases the probability of preferring a society with many at the bottom and one shaped like a pyramid. While this is in line with the disappointment hypothesis for aspirations, being unemployed, however, does not significantly affect stratification aspirations in Germany. Thus, the disappointment hypothesis is partly confirmed for German stratification aspirations.

In sum, we see that labour market outsiders in Germany (the unemployed) tend to have a rather inegalitarian image of the German stratification order. Looking at their stratification aspirations, however, we see that only those in part-time employment show significant egalitarian aspirations. Labour market outsiders in Germany, though disappointed by the German stratification reality, thus only hold moderate aspirations towards greater equality. This is partial support for the disappointment hypothesis, both for perceptions and aspirations. Moreover, those in full-time employment tend to hold unfavourable images of the German stratification order, but also aspire to a moderately more-but not too-egalitarian stratification order. Thus, the satisfaction hypothesis is partially supported for preferences, but not for perceptions.

\section{Cleavage Structures in Sweden}

In Sweden, we do not find any significant effects in line with either the satisfaction or disappointment hypotheses for perceived stratification realities (see Tables 2 and 5, Panel 1).

Looking at stratification aspirations in Sweden (Table 5, Panel 2), we find a large effect for gender, with women being more likely than men to prefer the most egalitarian forms of stratification (middle class, rich). Conversely, being female decreases the probability of preferring the most inegalitarian shape of stratification (small elite). This is not in line with the satisfaction hypothesis for aspirations in Sweden. However, looking at the interaction of gender with employment in the public sector, the pattern reverses.
Swedish women working in the public sector appear to have weaker egalitarian aspirations than their private-sector counterparts, as their probabilities for aspiring to the most egalitarian forms of society decrease, while the probability of preferring a society with a small elite and most people at the bottom increases. This finding is in line with the satisfaction hypothesis for aspirations. We do not find support for the disappointment hypothesis for aspirations in Sweden.

\section{Summary and Conclusions}

In this article, we asked how Americans, Germans, and Swedes assess the shape of stratification in their country (perceived stratification realities), whether this shape is in line with what they would prefer (stratification aspirations), and whether these perceptions differ systematically across welfare regimes and between social groups within each country. On the aggregate level, we find clear and interpretable differences across regimes. While Americans view their society as highly inegalitarian, their aspirations for a more egalitarian shape of stratification are smaller than those of Swedes or West Germans. Thus, perceptions of high levels of inequality do not automatically seem to translate into stronger egalitarian demands. This can also be observed with regard to the attitudes of East German respondents, which resemble those of Americans. East Germans and Americans display the most inegalitarian perceptions of the stratification reality of their respective society, but at the same time also have the lowest egalitarian aspirations. This is in line with previous research that suggests that the acceptance of inequality is higher in countries where people also perceive actual inequality to be high (Gijsberts, 2002; Osberg and Smeeding, 2006). Conversely, Swedes' perceptions of their stratification reality are the most equal ones, yet not quite as equal as they would like it. West Germans' perceptions are in between: while they resemble Swedes in their assessment of the German stratification reality, they do display smaller egalitarian aspirations. This ordering of countries corresponds to expectations that can be derived from welfare regime theory (Esping-Andersen, 1990).

While other researchers have found regime-specific differences in attitudes (e.g. in demand for redistribution) on the aggregate level (Svallfors, 1997, 2003; Andreß and Heien, 2001; Linos and West, 2003; Jaeger, 2006), little agreement has been reached over 
the existence of regime-specific attitudinal cleavages. Partly, this can be attributed to differences in the operationalization of dependent and independent variables, the selection of countries, and the specification of regime influence (Jaeger, 2006, 2009; Linos and West, 2003). However, most of these studies have used general normative statements about the support for government intervention and/or redistribution as dependent variables. Instead, our approach has focused on the public assessment of the particular shape of stratification in a given country as well as citizens respective preferences.

Looking at and comparing these two types of perceptions, we find some evidence of country-specific attitudinal cleavages in line with welfare regime theory. We find socio-economic differences for perceived stratification realities and stratification aspirations in the United States, labour market-insider/outsidercleavages for perceived stratification realities as well as (to some extent) aspirations in Germany, and a gender/sector cleavage for stratification aspirations in Sweden. However, our results are limited to the extent that the satisfaction- and disappointment-hypotheses for group differences receive only partial support: the hypotheses receive the strongest support in Germany, where we find effects in line with the expectations for both perceived realities and aspirations, and they receive less support in Sweden, where only the satisfaction hypothesis for stratification aspirations could be confirmed, and the United States, where only the satisfaction hypothesis for stratification realities could be confirmed. Overall, more evidence supports the satisfaction- than the disappointmenthypotheses. This indicates that aspirations towards greater equality do not seem to be closely related to the patterns of privilege and disadvantage set up (or induced) by the welfare state. This might help to explain why previous studies that focus solely on general normative attitudes towards redistribution rarely find regime-specific attitudinal cleavages.

Regarding the implications for welfare state theory, our results can be interpreted in line with recent theorizing that focuses on the role of ideas and culture in explaining welfare state development (Steensland, 2006; van Oorschot, 2007). While it is not our aim (and beyond the scope of our data) to provide direct evidence for the impact of ideational factors on the development of welfare states (e.g. their institutional design or the level of social expenditures), our results reveal a clear correspondence between the sociostructural/institutional reality of a given welfare regime and the attitudes of its citizens. Egalitarian aspirations are greatest in Sweden, the social democratic welfare regime under study here, and smallest in the liberal United States. While most previous research focuses on the influence of institutions on attitudes, recent evidence by Brooks and Manza (2006) suggests that social policy preferences of the population also influence welfare state spending. Thus, cultural factors such as mass policy preferences appear to play a role in welfare state development. Furthermore, ideas and cultural values are institutionalized within certain social policy programmes (Steensland 2006), and the correspondence between institutionalized and popular values is a crucial precondition for welfare state reform (Pfau-Effinger, 2009; Sachweh, Burkhardt and Mau, 2009). One of the tasks for future research in this direction would be to disentangle-both theoretically and empirically-the interrelationships between ideas, institutions, and public attitudes.

\section{Notes}

1. While we recognize that the welfare state is also a complex normative arrangement and a focus on self-interest alone is therefore inadequate to fully understand welfare state attitudes (Rothstein, 1998; Bowles and Gintis, 2000; Mau, 2003), it seems sufficient for the purpose of this article.

2. Moreover, institutions are also said to exert a cognitive influence on actors' preferences in that they 'provide information that helps individuals to navigate the social world's complexities' (Pierson, 1994, p. 41). Welfare state institutions thus influence individual attitudes also via the moral values and ideas they embody (Rothstein, 1998; Mau, 2003).

3. While widely referred to, Esping-Andersen's (1990) welfare regime typology was also subject to various forms of criticism. For instance, various proposals were made for adding a fourth regime type (e.g. Leibfried, 1992; Castles and Mitchell, 1993; Korpi and Palme, 1998). Moreover, the typology was also criticized on empirical grounds (Obinger and Wagschal, 1998) and for its gender-blindness (Orloff, 1993). For an overview on the discussion, see Arts and Gelissen (2002).

4. We chose not to use a class-based measure (e.g. EGP) since this would greatly increase the number of comparisons in the multinomial logit models 
as class variables often differentiate between several categories (Erikson and Goldthorpe, 1992). Moreover, since we do not derive specific hypotheses concerning particular classes (e.g. working class or service class) a more parsimonious measure of social position consisting of income and education seems appropriate.

5. The question wording is: 'It is the responsibility of the government to reduce the differences in income between people with high incomes and those with low incomes-strongly agree, agree, neither agree nor disagree, disagree, strongly disagree'.

6. More recently, a growing number of studies on welfare state attitudes also uses multilevel modelling (e.g. Jaeger, 2006; van Oorschot and Uunk, 2007). Since our main focus in the multivariate analyses is on regime-specific attitudinal cleavages and not on the influence of contextual factors on attitudes, we do not see multilevel modeling as the most appropriate statistical tool in our case. Besides, the small number of countries in the analysis would not fulfill the formal requirements posed for multilevel modeling (Hadler, 2005).

7. This finding is not in line with other findings on East-West differences in Germans' social policy attitudes (e.g. Roller, 1997; Noll and Roberts, 2003). See the Summary and concluding section for a discussion.

\section{Acknowledgements}

Previous versions of this article have been presented at the World Forum of Sociology in Barcelona in 2008 and the annual meeting of the Comparative Politics section of the German Political Science Association in Darmstadt in 2009. We thank the participants on these occasions for their input. Furthermore, we are grateful to Catherine Bolzendahl, Juan Fernandez, Nadine Reibling, and two anonymous reviewers for helpful comments on earlier versions of this article.

\section{Funding}

This work was supported by a Postdoctoral Fellowship of the Max Planck Society to P.S. for a stay at the Max Planck Institute for the Study of Societies in Cologne, Germany, during the academic year 2009/2010.

\section{References}

Alesina, A. and Glaeser, E. L. (2004). Fighting Poverty in the US and Europe. A World of Difference. Oxford: Oxford University Press.

Andreß, H.-J. and Heien, T. (2001). Four worlds of welfare state attitudes? A comparison of Germany, Norway, and the United States. European Sociological Review, 17, 337-356.

Arts, W. and Gelissen, J. (2002). Three worlds of welfare capitalism or more? A state-of-the-art report. Journal of European Social Policy, 12, 137-158.

Beller, E. and Hout, M. (2006). Welfare states and social mobility: how educational and social policy may affect the cross-national differences in the association between occupational origins and destinations. Research in Social Stratification and Mobility, 24, 353-365.

Bolzendahl, C. and Olafsdottir, S. (2008). Private problems or public solutions? Understanding U.S. support for family policy in a comparative perspective. Sociological Perspectives, 51, 281-304.

Bowles, S. and Gintis, H. (2000). Reciprocity, selfinterest, and the welfare state. Nordic Journal of Political Economy, 26, 33-53.

Bradley, D., Huber, E., Moller, S., Nielsen, F. et al. (2003). Distribution and redistribution in postindustrial democracies. World Politics, 55, 193-228.

Brady, D. (2003). The politics of poverty: left political institutions, the welfare state, and poverty. Social Forces, 82, 557-588.

Brooks, C. and Manza, J. (2006). Social policy responsiveness in developed democracies. American Sociological Review, 71, 474-494.

Castles, F. G. and Mitchell, D. (1993). Worlds of welfare and families of nations. In Castles, F. G. (Ed.), Families of Nations. Patterns of Public Policy in Western Democracies. Aldershot: Dartmouth, pp. 93-128.

DiPrete, T. A. (2002). Life course risks, mobility regimes, and mobility consequences: a comparison of Sweden, Germany, and the United States. American Journal of Sociology, 108, 267-309.

DiPrete, T. A. (2007). Is this a great country? Upward mobility and the chance for riches in contemporary America. Research in Social Stratification and Mobility, 25, 89-95.

Ebbinghaus, B. (2005). When less is more: selection problems in large- $\mathrm{N}$ and small- $\mathrm{N}$ cross-national comparisons. International Sociology, 20, 133-152.

Erikson, R. and Goldthorpe, J. H. (1992). The Constant Flux. A Study of Class Mobility in Industrial Societies. Oxford: Clarendon Press. 
Erikson, R. and Jonsson, J. O. (1996). Introduction: explaining class inequality in education: The Swedish test case. In Erikson, R. and Jonsson, J. O. (Eds.), Can Education be Equalized?. Boulder, CO: Westview, pp. 1-64.

Esping-Andersen, G. (1990). The Three Worlds of Welfare Capitalism. London: Polity Press.

Esping-Andersen, G. (2004). Untying the Gordian knot of social inheritance. Research in Social Stratification and Mobility, 21, 115-138.

Esping-Andersen, G. (2005). Inequality of income and opportunities. In Giddens, A. and Diamand, P. (Eds.), The New Egalitarianism. Cambridge: Polity Press, pp. 8-38.

Flora, P., Alber, J. and Kohl, J. (1977). Zur Entwicklung der westeuropäischen Wohlfahrtsstaaten. Politische Vierteljahresschrift, 18, 705-772.

Fouarge, D. and Layte, R. (2005). Welfare regimes and poverty dynamics. The duration and recurrence of poverty spells in Europe. Journal of Social Policy, 34, 407-426.

Fuwa, M. (2004). Macro-level gender inequality and the division of household labor in 22 countries. American Sociological Review, 69, 751-767.

Geist, C. (2003). The welfare state and the home: regime differences in the domestic division of labor. European Sociological Review, 21, 23-41.

Gijsberts, M. (2002). The legitimation of income inequality in state-socialist and market societies. Acta Sociologica, 45, 269-285.

Goodin, R., Headey, B., Muffels, R. and Dirven, H.-J. (1999). The Real Worlds of Welfare Capitalism. New York: Cambridge University Press.

Hadler, M. (2005). Die Mehrebenen-Analyse. Ihre praktische Anwendung und theoretische Annahmen. Österreichische Zeitschrift für Soziologie, 29, $53-74$.

Hayes, B. C. and VandenHeuvel, A. (1996). Government spending on health care: a cross-national study of public attitudes. Journal of Health and Social Policy, 7, 61-79.

Jaeger, M. M. (2006). Welfare regimes and attitudes towards redistribution: the regime hypothesis revisited. European Sociological Review, 22, 157-170.

Jaeger, M. M. (2009). United but divided: welfare regimes and the level and variance in public support for redistribution. European Sociological Review, 25, 723-737.

Kelley, J. and Evans, M. D. R. (1993). The legitimation of inequality. Occupational earnings in nine nations. American Journal of Sociology, 99, $75-125$.
Kenworthy, L. (1999). Do social-welfare policies reduce poverty? A cross-national assessment. Social Forces, 77, 1119-1139.

Kenworthy, L. and McCall, L. (2008). Inequality, public opinion, and redistribution. Socio-Economic Review, 6, 35-68.

Kenworthy, L. and Pontusson, J. (2005). Rising inequality and the politics of redistribution in affluent countries. Perspectives on Politics, 3, 449-471.

Kikuzawa, S., Olafsdottir, S. and Pescosolido, B. (2008). Similar pressures, different context: public attitudes to government intervention for health care in 21 nations. Journal of Health and Social Behavior, 49, 385-399.

Kittel, B. (2006). A crazy methodology? On the limits of macro-quantitative social science research. International Sociology, 21, 647-677.

Kluegel, J. S. and Smith, E. (1986). Beliefs About Inequality. American's View of What is and What Ought to be. New York: Aldine de Gruyter.

Korpi, W. and Palme, J. (1998). The paradox of redistribution and strategies of equality: welfare state institutions, inequality, and poverty in the Western countries. American Sociological Review, 63, 661-687.

Kumlin, S. (2004). The Personal and the Political: How Personal Welfare State Experiences Affect Political Trust and Ideology. Basingstoke: Palgrave Macmillan.

Leibfried, S. (1992). Towards a European welfare state? On integrating poverty regimes into the European Community. In Ferge, Z. and Kolberg, J. E. (Eds.), Social Policy in a Changing Europe. Frankfurt: Campus, pp. 245-278.

Leitner, S. and Lessenich, S. (2003). Assessing welfare state change: the German welfare state between reciprocity and solidarity. Journal of Public Policy, 23, 325-347.

Lewin-Epstein, N., Kaplan, A. and Levanon, A. (2003). Distributive justice and attitudes towards the welfare state. Social Justice Research, 16, 1-27.

Linos, K. and West, M. (2003). Self-interest, social beliefs, and attitudes to redistribution. Re-addressing the issue of cross-national variation. European Sociological Review, 19, 393-409.

Long, J. S. (1997). Regression Models for Categorical and Limited Dependent Variables. Thousand Oaks: Sage.

Long, J. S. and Freese, J. (2001). Regression models for categorical dependent variables using stata. College Station: Stata Press.

Marshall, T. H. (1950). Citizenship and social class and other essays. Cambridge: Cambridge University Press. 
Mau, S. (2003). The Moral Economy of Welfare States. Britain and Germany Compared. London: Routledge.

Meltzer, A. H. and Richard, S. F. (1981). A rational theory of the size of government. The Journal of Political Economy, 89, 914-927.

Müller, W. and Pollak, R. (2004). Social mobility in West Germany: the long arms of history discovered? In Breen, R. (Ed.), Social Mobility in Europe. Oxford: Oxford University Press, pp. 77-113.

Noll, H.-H. and Roberts, L. W. (2003). The legitimacy of inequality on both sides of the Atlantic. A comparative analysis of attitudes in Canada and Germany. The Tocqueville Review, 24, 1-37.

Obinger, H. and Wagschal, U. (1998). Drei Welten des Wohlfahrtsstaates? Das Stratifizierungskonzept in der clusteranalytischen Überprüfung. In Lessenich, S. and Ostner, I. (Eds.), Welten des Wohlfahrtskapitalismus. Der Sozialstaat in vergleichender Perspektive. Frankfurt am Main: Campus, pp. 109-135.

Offe, C. (1998). Der deutsche Wohlfahrtsstaat: Prinzipien, Leistungen, Zukunftsaussichten. Berliner Journal für Soziologie, 1, 359-380.

Olafsdottir, S. (2007). Fundamental causes of health disparities: stratification, the welfare state, and health in the United States and Iceland. Journal of Health and Social Behavior, 48, 239-253.

Orloff, A. S. (1993). Gender and the social rights of citizenship. The comparative analysis of gender relations and welfare states. American Sociological Review, 58, 303-328.

Osberg, L. and Smeeding, T. (2006). "Fair" inequality? Attitudes toward pay differentials: The United States in comparative perspective. American Sociological Review, 71, 450-473.

Palme, J. (2006). Welfare states and inequality: institutional designs and distributive outcome. Research in Social Stratification and Mobility, 24, 387-403.

Pescosolido, B., Boyer, C. A. and Tsui, W. Y. (1985). Medical care in the welfare state: a cross-national study of public evaluations. Journal of Health and Social Behavior, 26, 276-297.

Pfau-Effinger, B. (2009). Wohlfahrtsstaatliche Politiken und ihre kulturellen Grundlagen. Österreichische Zeitschrift für Soziologie, 34, 3-21.

Pierson, P. (1994). Dismantling the Welfare State? Reagan, Thatcher and the Politics of Retrenchment. Cambridge: Cambridge University Press.

Rehm, P. (2007). Who supports the welfare state? Determinants of preferences concerning redistribution. In Mau, S. and Veghte, B. (Eds.), Social Justice, Legitimacy, and the Welfare State. Aldershot: Ashgate, pp. 47-72.

Roller, E. (1995). The welfare state: the equality dimension. In Borre, O. and Scarbrough, E. (Eds.), The Scope of Government. Oxford: Oxford University Press, pp. 165-197.

Roller, E. (1997). Sozialpolitische Orientierungen nach der deutschen Vereinigung. In Gabriel, O. W. (Ed.), Politsche Orientierungen und Verhaltensweisen im vereinigten Deutschland. Opladen: Leske+ Budrich, pp. 115-146.

Romer, T. (1975). Individual welfare, majority voting, and the properties of a linear income tax. Journal of Public Economics, 14, 163-185.

Rothstein, B. (1998). Just Institutions Matter. The Moral and Political Logic of the Universal Welfare State. Cambridge: Cambridge University Press.

Sachweh, P., Burkhardt, C. and Mau, S. (2009). Wandel und Reform des deutschen Sozialstaats aus der Sicht der Bevölkerung. WSI Mitteilungen, 62, 612-618.

Sachweh, P., Ullrich, C. G. and Christoph, B. (2007). The moral economy of poverty: on the conditionality of public support for social assistance schemes. In Mau, S. and Veghte, B. (Eds.), Social Justice, Legitimacy, and the Welfare State. Aldershot: Ashgate, pp. 123-142.

Scruggs, L. A. and Allan, J. P. (2008). Social stratification and welfare regimes for the 21st century: revisiting the "Three Worlds of Welfare Capitalism". World Politics, 60, 642-646.

Sørensen, A. (2006). Welfare states, family inequality, and equality of opportunity. Research in Social Stratification and Mobility, 24, 367-375.

Steensland, B. (2006). Cultural categories and the American welfare state: the case of guaranteed income policy. American Journal of Sociology, 111, 1273-1326.

Stimson, J. A., MacKuen, M. B. and Erikson, R. S. (1995). Dynamic representation. American Political Science Review, 89, 543-565.

Svallfors, S. (1993). Dimensions of inequality: a comparison of attitudes in Sweden and Britain. European Sociological Review, 9, 267-287.

Svallfors, S. (1997). Worlds of welfare and attitudes toward redistribution. European Sociological Review, 13, 283-304.

Svallfors, S. (2003). Welfare regimes and welfare opinions: a comparison of eight western countries. Social Indicators Research, 64, 495-520.

Titmuss, R. M. (1968). Commitment to Welfare. London: Unwin University Books. 
van Oorschot, W. (2007). Culture and social policy: a developing field of study. International Journal of Social Welfare, 16, 129-139.

van Oorschot, W. (2010). Public perceptions of the economic, moral, social and migration consequences of the welfare state: an empirical analysis of welfare state legitimacy. Journal of European Social Policy, 20, 19-31.

van Oorschot, W. and Uunk, W. (2007). Multi-level determinants of the public's informal solidarity towards immigrants in European welfare states. In Mau, S. and Veghte, B. (Eds.), Social Justice, Legitimacy and the Welfare State. Aldershot: Ashgate, pp. 217-238.

Wilensky, H. (1975). The Welfare State and Equality. Structural and Ideological Roots of Public Expenditures. Berkeley: University of California Press.

\section{Authors' Addresses}

Patrick Sachweh (to whom correspondence should be addressed), Department of Social Sciences, Goethe University Frankfurt, Robert-Mayer-Str. 1, 60054 Frankfurt/Main, Germany. Email: sachweh@ soz.uni-frankfurt.de

Sigrun Olafsdottir, Department of Sociology, Boston University, 96 Cummington Street, Boston, MA 02215, USA. Email: sigrun@bu.edu

Manuscript received: September 2010

\section{Appendix}

"These five diagrams show different types of society. Please read the descriptions and look at the diagrams and decide which you think best describes [COUNTRY] today."

Type 1
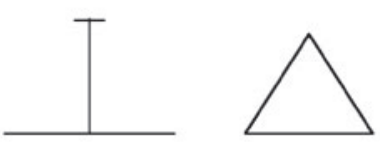

Type 3



Type 4

Type 5

Type 1 "A small elite at the top, very few people in the middle and the great mass of people at the bottom." [= 1) Small Elite]

Type 2 "A society like a pyramid with a small elite at the top, more people in the middle, and most at the bottom." [= 2) Pyramid]

Type 3 "A pyramid except that just a few people are at the very bottom." [=3) Christmas Tree]

Type 4 "A society with most people in the middle." [=4) Middle]

Type 5 "Many people near the top, and only a few near the bottom." [= 5) Rich]

Perceived Stratification Realities: "First, what type of society is [COUNTRY] today?"

Stratification Aspirations:
"What do you think [COUNTRY] ought to be like?"

Figure A1 Question wording of the dependent variables 
Table A1 Descriptive statistics

United States West Germany East Germany Sweden

\begin{tabular}{lcccc}
\hline Age (years) & $43(16)$ & $47(16)$ & $49(18)$ & $45(15)$ \\
Female (=1) & $0.54(0.50)$ & $0.49(0.50)$ & $0.50(0.50)$ & $0.50(0.50)$ \\
College (=1) & $0.23(0.42)$ & $0.08(0.28)$ & $0.09(0.29)$ & $0.19(0.44)$ \\
Income & & & & \\
$\quad$ Relative affluence & $0.22(0.41)$ & $0.28(0.45)$ & $0.12(0.32)$ & $0.25(0.43)$ \\
$\quad$ Income middle & $0.59(0.49)$ & $0.55(0.50)$ & $0.63(0.48)$ & $0.57(0.49)$ \\
$\quad$ Relative poverty & $0.20(0.40)$ & $0.17(0.37)$ & $0.25(0.43)$ & $0.18(0.38)$ \\
Employment status & & & & \\
$\quad$ Employed full-time & $0.57(0.49)$ & $0.51(0.50)$ & $0.48(0.50)$ & $0.57(0.50)$ \\
$\quad$ Employed part-time & $0.13(0.33)$ & $0.06(0.24)$ & $0.05(0.21)$ & $0.15(0.36)$ \\
$\quad$ Unemployed & $0.03(0.16)$ & $0.04(0.19)$ & $0.11(0.31)$ & $0.03(0.17)$ \\
$\quad$ Retired & $0.10(0.31)$ & $0.21(0.41)$ & $0.31(0.46)$ & $0.13(0.33)$ \\
$\quad$ Not in labour force & $0.17(0.38)$ & $0.18(0.39)$ & $0.05(0.22)$ & $0.12(0.32)$ \\
Public sector (= 1) & $0.09(0.29)$ & $0.14(0.35)$ & $0.13(0.34)$ & $0.45(0.50)$ \\
Support for redistribution & $2.94(1.22)$ & $3.22(1.17)$ & $3.96(0.94)$ & $3.55(1.17)$ \\
$N$ & 896 & 568 & 358 & 880 \\
\hline
\end{tabular}

Note: Mean values, standard deviation in parentheses.

Table A2 Change in predicted probabilities for perceived stratification realities and stratification aspirations, United States

Independent variables Chang

Categories of dependent variable

\begin{tabular}{|c|c|c|c|c|c|c|}
\hline & & $\begin{array}{l}\text { (1) Small } \\
\text { elite }\end{array}$ & $\begin{array}{c}(2) \\
\text { Pyramid }\end{array}$ & $\begin{array}{c}\text { (3) Christmas } \\
\text { tree }\end{array}$ & $\begin{array}{l}\text { (4) Middle } \\
\text { class }\end{array}$ & $\begin{array}{c}(5) \\
\text { Rich }\end{array}$ \\
\hline \multicolumn{7}{|l|}{ Panel 1: Realities } \\
\hline Age & $\Delta \sigma$ & 0.02 & 0.00 & 0.00 & -0.03 & 0.00 \\
\hline Female & $0 \rightarrow 1$ & -0.05 & 0.04 & 0.02 & -0.01 & -0.00 \\
\hline College & $0 \rightarrow 1$ & -0.09 & -0.07 & 0.08 & 0.09 & -0.01 \\
\hline \multicolumn{7}{|c|}{ Income (Ref.: income middle) } \\
\hline Relative affluence & $0 \rightarrow 1$ & -0.03 & -0.00 & -0.00 & 0.03 & -0.00 \\
\hline Relative poverty & $0 \rightarrow 1$ & 0.00 & 0.01 & -0.00 & -0.01 & -0.00 \\
\hline \multicolumn{7}{|c|}{ Employment status (Ref.: not in labour force) } \\
\hline Employed full-time & $0 \rightarrow 1$ & -0.05 & 0.08 & -0.03 & 0.01 & -0.01 \\
\hline Employed part-time & $0 \rightarrow 1$ & -0.05 & 0.01 & -0.12 & 0.17 & -0.01 \\
\hline Unemployed & $0 \rightarrow 1$ & 0.07 & -0.07 & -0.05 & 0.06 & -0.02 \\
\hline Retired & $0 \rightarrow 1$ & -0.03 & 0.12 & -0.07 & -0.02 & -0.00 \\
\hline Public sector & $0 \rightarrow 1$ & 0.06 & -0.01 & 0.04 & -0.08 & -0.00 \\
\hline Support for redistribution & $\Delta \sigma$ & 0.06 & 0.03 & -0.02 & -0.07 & 0.00 \\
\hline \multicolumn{7}{|l|}{ Panel 2: Aspirations } \\
\hline Age & $\Delta \sigma$ & 0.00 & -0.01 & 0.02 & 0.00 & -0.01 \\
\hline Female & $0 \rightarrow 1$ & 0.00 & -0.04 & -0.01 & 0.04 & 0.00 \\
\hline College & $0 \rightarrow 1$ & -0.02 & -0.04 & -0.05 & 0.06 & 0.04 \\
\hline \multicolumn{7}{|c|}{ Income (Ref.: income middle) } \\
\hline Relative affluence & $0 \rightarrow 1$ & 0.00 & 0.03 & 0.03 & -0.05 & -0.01 \\
\hline Relative poverty & $0 \rightarrow 1$ & -0.00 & -0.00 & 0.06 & -0.05 & -0.02 \\
\hline \multicolumn{7}{|c|}{ Employment status (Ref.: not in labour force) } \\
\hline Employed full-time & $0 \rightarrow 1$ & -0.00 & -0.03 & 0.02 & -0.01 & 0.02 \\
\hline Employed part-time & $0 \rightarrow 1$ & -0.00 & -0.07 & 0.01 & 0.04 & 0.02 \\
\hline Unemployed & $0 \rightarrow 1$ & 0.00 & -0.02 & -0.10 & 0.09 & 0.03 \\
\hline Retired & $0 \rightarrow 1$ & $4.44 e-06$ & 0.04 & 0.09 & -0.01 & -0.12 \\
\hline Public sector & $0 \rightarrow 1$ & $5.13 e-06$ & 0.03 & 0.10 & -0.03 & -0.10 \\
\hline Support for redistribution & $\Delta \sigma$ & $8.94 e-06$ & 0.00 & -0.02 & -0.01 & 0.03 \\
\hline
\end{tabular}

Note: $0 \rightarrow 1$ is the discrete change from 0 to $1 . \Delta \sigma$ is the centred change of one standard deviation around the mean. 
Table A3 Change in predicted probabilities for perceived stratification realities and stratification aspirations, Germany

Independent variables

Change

Categories of dependent variable

\begin{tabular}{ccccc}
\hline $\begin{array}{c}\text { (1) Small } \\
\text { elite }\end{array}$ & $\begin{array}{c}\text { (2) } \\
\text { Pyramid }\end{array}$ & $\begin{array}{c}\text { (3) Christmas } \\
\text { tree }\end{array}$ & $\begin{array}{c}\text { (4) Middle } \\
\text { class }\end{array}$ & $\begin{array}{c}\text { (5) } \\
\text { Rich }\end{array}$
\end{tabular}

\begin{tabular}{|c|c|c|c|c|c|c|}
\hline \multicolumn{7}{|l|}{ Panel 1: Realities } \\
\hline Age & $\Delta \sigma$ & 0.02 & 0.02 & -0.00 & -0.03 & -0.00 \\
\hline Female & $0 \rightarrow 1$ & 0.02 & 0.04 & -0.04 & -0.02 & 0.00 \\
\hline College & $0 \rightarrow 1$ & 0.04 & -0.07 & 0.01 & 0.03 & -0.02 \\
\hline \multicolumn{7}{|c|}{ Income (Ref.: income middle) } \\
\hline Relative affluence & $0 \rightarrow 1$ & -0.06 & -0.01 & -0.01 & 0.08 & -0.00 \\
\hline Relative poverty & $0 \rightarrow 1$ & 0.06 & -0.03 & -0.04 & -0.00 & 0.00 \\
\hline \multicolumn{7}{|c|}{ Employment status (Ref.: not in labour force) } \\
\hline Employed full-time & $0 \rightarrow 1$ & 0.01 & 0.13 & -0.09 & -0.05 & 0.01 \\
\hline Employed part-time & $0 \rightarrow 1$ & -0.07 & 0.20 & -0.09 & -0.05 & 0.01 \\
\hline Unemployed & $0 \rightarrow 1$ & 0.05 & 0.18 & -0.11 & -0.13 & 0.01 \\
\hline Retired & $0 \rightarrow 1$ & -0.03 & 0.00 & -0.01 & 0.04 & 0.01 \\
\hline Public sector & $0 \rightarrow 1$ & -0.03 & -0.07 & 0.07 & 0.03 & -0.00 \\
\hline East Germany & $0 \rightarrow 1$ & 0.04 & 0.02 & -0.03 & -0.02 & 0.00 \\
\hline Support for redistribution & $\Delta \sigma$ & 0.05 & -0.01 & -0.02 & -0.02 & 0.00 \\
\hline \multicolumn{7}{|l|}{ Panel 2: Aspirations } \\
\hline Age & $\Delta \sigma$ & 0.00 & 0.03 & 0.03 & 0.02 & -0.07 \\
\hline Female & $0 \rightarrow 1$ & -0.00 & -0.03 & 0.06 & 0.00 & -0.04 \\
\hline College & $0 \rightarrow 1$ & -0.00 & -0.01 & 0.01 & 0.02 & -0.02 \\
\hline \multicolumn{7}{|c|}{ Income (Ref.: income middle) } \\
\hline Relative affluence & $0 \rightarrow 1$ & 0.00 & -0.01 & 0.06 & -0.14 & 0.09 \\
\hline Relative poverty & $0 \rightarrow 1$ & -0.00 & -0.00 & -0.02 & 0.02 & 0.00 \\
\hline \multicolumn{7}{|c|}{ Employment status (Ref.: not in labour force) } \\
\hline Employed fulltime & $0 \rightarrow 1$ & -0.00 & -0.07 & 0.11 & 0.06 & -0.10 \\
\hline Employed part-time & $0 \rightarrow 1$ & -0.01 & -0.09 & 0.02 & 0.10 & -0.03 \\
\hline Unemployed & $0 \rightarrow 1$ & -0.00 & -0.05 & 0.16 & -0.02 & -0.09 \\
\hline Retired & $0 \rightarrow 1$ & -0.00 & -0.05 & 0.08 & -0.02 & -0.00 \\
\hline Public sector & $0 \rightarrow 1$ & 0.00 & 0.03 & 0.02 & -0.10 & 0.04 \\
\hline East Germany & $0 \rightarrow 1$ & 0.00 & 0.02 & 0.01 & -0.17 & 0.13 \\
\hline Support for redistribution & $\Delta \sigma$ & 0.00 & -0.01 & -0.01 & -0.01 & 0.02 \\
\hline
\end{tabular}

Note: $0 \rightarrow 1$ is the discrete change from 0 to $1 . \Delta \sigma$ is the centred change of one standard deviation around the mean. 
Table A4 Change in predicted probabilities in perceived stratification realities and stratification aspirations, Sweden

Independent variables

Change

Categories of dependent variable

\begin{tabular}{ccccc}
\hline $\begin{array}{c}\text { (1) Small } \\
\text { elite }\end{array}$ & $\begin{array}{c}\text { (2) } \\
\text { Pyramid }\end{array}$ & $\begin{array}{c}\text { (3) Christmas } \\
\text { tree }\end{array}$ & $\begin{array}{c}\text { (4) Middle } \\
\text { class }\end{array}$ & $\begin{array}{c}\text { (5) } \\
\text { Rich }\end{array}$
\end{tabular}

\begin{tabular}{|c|c|c|c|c|c|c|}
\hline \multicolumn{7}{|l|}{ Panel 1: Realities } \\
\hline Age & $\Delta \sigma$ & 0.04 & 0.09 & -0.06 & -0.07 & 0.00 \\
\hline Female & $0 \rightarrow 1$ & -0.01 & 0.02 & -0.06 & 0.06 & 0.00 \\
\hline College & $0 \rightarrow 1$ & -0.04 & -0.13 & 0.10 & 0.07 & -0.00 \\
\hline \multicolumn{7}{|c|}{ Income (Ref.: income middle) } \\
\hline Relative affluence & $0 \rightarrow 1$ & -0.06 & -0.03 & 0.02 & 0.08 & -0.00 \\
\hline Relative poverty & $0 \rightarrow 1$ & 0.02 & 0.00 & -0.00 & -0.02 & 0.00 \\
\hline \multicolumn{7}{|c|}{ Employment status (Ref.: not in labour force) } \\
\hline Employed fulltime & $0 \rightarrow 1$ & 0.01 & -0.03 & -0.00 & 0.03 & -0.00 \\
\hline Employed part-time & $0 \rightarrow 1$ & -0.02 & -0.01 & 0.01 & 0.02 & -0.01 \\
\hline Unemployed & $0 \rightarrow 1$ & -0.04 & 0.11 & 0.01 & -0.08 & -0.00 \\
\hline Retired & $0 \rightarrow 1$ & -0.06 & -0.08 & 0.09 & 0.05 & -0.00 \\
\hline Public sector & $0 \rightarrow 1$ & 0.03 & 0.02 & -0.04 & -0.00 & 0.00 \\
\hline Female $\times$ public sector & $0 \rightarrow 1$ & -0.02 & -0.03 & 0.01 & -0.03 & -0.00 \\
\hline Support for redistribution & $\Delta \sigma$ & 0.05 & 0.05 & 0.01 & -0.11 & -0.00 \\
\hline \multicolumn{7}{|l|}{ Panel 2: Aspirations } \\
\hline Age & $\Delta \sigma$ & -0.00 & 0.01 & 0.07 & -0.04 & -0.04 \\
\hline Female & $0 \rightarrow 1$ & -0.73 & 0.02 & 0.02 & 0.33 & 0.35 \\
\hline College & $0 \rightarrow 1$ & -0.00 & 0.03 & -0.04 & -0.02 & -0.01 \\
\hline \multicolumn{7}{|c|}{ Income (Ref.: income middle) } \\
\hline Relative affluence & $0 \rightarrow 1$ & 0.00 & -0.01 & 0.04 & 0.00 & -0.04 \\
\hline Relative poverty & $0 \rightarrow 1$ & 0.00 & 0.01 & 0.02 & 0.03 & -0.06 \\
\hline \multicolumn{7}{|c|}{ Employment status (Ref.: not in labour force) } \\
\hline Employed full-time & $0 \rightarrow 1$ & -0.00 & 0.00 & -0.03 & -0.01 & 0.04 \\
\hline Employed part-time & $0 \rightarrow 1$ & -0.00 & 0.02 & -0.04 & 0.05 & -0.03 \\
\hline Unemployed & $0 \rightarrow 1$ & -0.00 & 0.00 & -0.03 & 0.31 & -0.28 \\
\hline Retired & $0 \rightarrow 1$ & 0.00 & 0.03 & -0.06 & 0.13 & -0.09 \\
\hline Public sector & $0 \rightarrow 1$ & -0.00 & 0.01 & -0.01 & -0.03 & 0.03 \\
\hline Female $\times$ public sector & $0 \rightarrow 1$ & 1.00 & -0.05 & -0.07 & -0.49 & -0.39 \\
\hline Support for redistribution & $\Delta \sigma$ & -0.00 & -0.00 & -0.02 & 0.02 & 0.01 \\
\hline
\end{tabular}

Note: $0 \rightarrow 1$ is the discrete change from 0 to $1 . \Delta \sigma$ is the centred change of one standard deviation around the mean. 